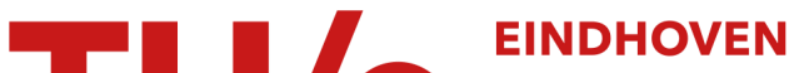 UNIVERSITY OF TECHNOLOGY
}

\section{Relations between composition and microstructure of sialons}

Citation for published version (APA):

Cao, G. Z., Metselaar, R., \& Ziegler, G. (1993). Relations between composition and microstructure of sialons. Journal of the European Ceramic Society, 11(2), 115-122. https://doi.org/10.1016/0955-2219(93)90042-P

DOI:

10.1016/0955-2219(93)90042-P

Document status and date:

Published: 01/01/1993

\section{Document Version:}

Publisher's PDF, also known as Version of Record (includes final page, issue and volume numbers)

\section{Please check the document version of this publication:}

- A submitted manuscript is the version of the article upon submission and before peer-review. There can be important differences between the submitted version and the official published version of record. People interested in the research are advised to contact the author for the final version of the publication, or visit the $\mathrm{DOI}$ to the publisher's website.

- The final author version and the galley proof are versions of the publication after peer review.

- The final published version features the final layout of the paper including the volume, issue and page numbers.

Link to publication

\section{General rights}

Copyright and moral rights for the publications made accessible in the public portal are retained by the authors and/or other copyright owners and it is a condition of accessing publications that users recognise and abide by the legal requirements associated with these rights.

- Users may download and print one copy of any publication from the public portal for the purpose of private study or research.

- You may not further distribute the material or use it for any profit-making activity or commercial gain

- You may freely distribute the URL identifying the publication in the public portal.

If the publication is distributed under the terms of Article $25 \mathrm{fa}$ of the Dutch Copyright Act, indicated by the "Taverne" license above, please follow below link for the End User Agreement:

www.tue.nl/taverne

Take down policy

If you believe that this document breaches copyright please contact us at:

openaccess@tue.nl

providing details and we will investigate your claim. 


\title{
Relations Between Composition and Microstructure of Sialons
}

\author{
G. Z. Cao, R. Metselaar
}

Centre for Technical Ceramics, Eindhoven University of Technology, PO Box 513, 5600 MB Eindhoven, The Netherlands

$\&$

\section{G. Ziegler}

Institute for Materials Research, Bayreuth University, 8580 Bayreuth, Germany

(Received 24 March 1992; accepted 7 July 1992)

\begin{abstract}
The relationship between composition and microstructure of sialon ceramics was studied. Fully dense yttrium-containing $\alpha^{\prime}$ - and $\alpha^{\prime}+\beta^{\prime}$-sialon ceramics were prepared by gas pressure sintering. Additionally, the effect of $\mathrm{La}_{2} \mathrm{O}_{3}$ as a sintering additive was investigated. Experimental results reveal that the typical microstructure of these sialon ceramics consists of a crystalline phase of sialon( $s$ ) and a small fraction of amorphous phase remaining at grain boundaries. The composition of the amorphous phase is very similar, both in $\alpha^{\prime}$-and $\alpha^{\prime}+\beta^{\prime}$-sialon ceramics. However, the amount of the amorphous phase increases with increasing amount of oxides used in the starting mixtures. The $\alpha^{\prime}$ - and $\alpha^{\prime}+\beta^{\prime}$-sialons exhibit differences in grain size and grain morphology. The addition of $\mathrm{La}_{2} \mathrm{O}_{3}$ to the starting mixtures promotes the incorporation of yttrium ions into the crystal lattice and leads to the formation of crystal defects in the $\alpha^{\prime}$-grains.
\end{abstract}

Ess wurde der Zusammenhang zwischen Zusammensetzung und Gefüge von Sialon-Keramiken untersucht. Vollständig verdichtete Yttrium-haltige $\alpha^{\prime}+\beta^{\prime}-$ Sialon-Keramiken wurden durch Gasdrucksintern hergestellt. Des weiteren wurde der Einfluß von $\mathrm{La}_{2} \mathrm{O}_{3}$ als Sinteradditiv untersucht. Die experimentellen Ergebnisse zeigen, daß ein typisches Gefüge dieser Sialon-Keramiken aus einer kristallinen Sialon-Phase und einem geringen Anteil verbleibender amorpher Phase an den Korngrenzen besteht. Die Zusammensetzung der amorphen Phase ist sehr einheitlich, sowohl in $\alpha^{\prime}$-als auch in $\alpha^{\prime}+\beta^{\prime}$-Sialon-Keramiken. Der Anteil an amorpher Phase nimmt jedoch mit steigendem Anteil an Oxiden in den Ausgangs- mischungen zu. Die $\alpha^{\prime}$ - und $\alpha^{\prime}+\beta^{\prime}$-Sialone weisen Unterschiede in Korngröße und-morphologie auf. Der Zusatz von $\mathrm{La}_{2} \mathrm{O}_{3}$ zu den Ausgangsmischungen beschleunigt das Eindringen der Yttriumionen in das Kristallgitter und führt zur Bildung von Kristalldefekten innerhalb der $\alpha^{\prime}$-Körner.

Les auteurs ont étudié la relation entre la composition et la microstructure de céramiques en sialon. Des céramiques tout-à-fait denses en sialon $\alpha^{\prime}$ et $\alpha^{\prime}+\beta^{\prime}$ contenant de l'yttrium ont été préparées par frittage sous pression gazeuse (GPS). De plus, l'effet de $\mathrm{La}_{2} \mathrm{O}_{3}$ en tant qu'additif de frittage a été examiné. Les résultats expérimentaux montrent que la microstructure typique de ces sialons consiste en une phase cristalline en sialon et en une petite fraction de phase amorphe localisée aux joints de grains. Dans les deux cas examinés ( $\alpha^{\prime}$ et $\alpha^{\prime}+\beta^{\prime}$ ), la composition de la phase amorphe est très semblable. Cependant, sa quantité augmente avec la quantité d'oxydes présents dans le mélange de départ. Les sialons $\alpha^{\prime}$ et $\alpha^{\prime}+\beta^{\prime}$ se distinguent par leur taille et leur morphologie des grains. L'addition de $\mathrm{La}_{2} \mathrm{O}_{3}$ dans la composition initiale favorise l'incorporation des ions yttrium dans le réseau cristallin et conduit à la formation de défauts cristallins dans les grains $\alpha^{\prime}$.

\section{Introduction}

The $\alpha^{\prime}$-and/or mixed $\alpha^{\prime}+\beta^{\prime}$-sialon ceramics have attracted attention both as cutting tools and as potential materials used at high temperatures and in corrosive environments. In this respect it is important that $\alpha^{\prime}$-sialons offer the possibility to incorporate the sintering aids, like yttria, into the lattice ${ }^{1,2}$ and 
thus enhance the chemical and mechanical properties, especially at high temperatures. It is proposed that by combination of careful processing and heat treatment the amount of glassy grain boundary phase can be kept very low ${ }^{3}$ or can be fully crystallized. ${ }^{4}$ It has also been shown that advanced sintering techniques such as gas pressure sintering and hot isostatic pressing can be used successfully to obtain fully dense sialon ceramics. ${ }^{5-8}$ In the present study the relationship between the amount and composition of oxide additive(s) and the microstructure of the final sialon ceramics is discussed.

Cations, such as $\mathrm{La}^{3+}$ or $\mathrm{Ce}^{3+}$, are considered to be too large to be incorporated into the crystal lattice, ${ }^{1-3}$ but it has been shown that as sintering additives for silicon nitride and/or sialon ceramics they can improve the sinterability and mechanical properties. ${ }^{9-11}$ Thus, $\mathrm{La}_{2} \mathrm{O}_{3}$ as an extra sintering additive was used for improving the formation of sialon and the final densification, and modifying the composition of the glassy grain boundary phase. Recently Olsson ${ }^{12}$ and Ekström et al. $^{13}$ reported that $\mathrm{Ce}^{3+}$ cations (radius $1.034 \AA$ ) can enter the lattice of $\alpha^{\prime}$-sialons. Thus, it is also of interest to see whether $\mathrm{La}^{3+}$ cations (radius 1.061 $\AA$ ), together with $\mathrm{Y}^{3+}$ (radius 0.892 $\AA$ ) are soluble too.

\section{Experimental Procedure}

The starting materials used in the present investigation were $\mathrm{Si}_{3} \mathrm{~N}_{4}$ (LC-12, Starck, Berlin, Germany, with $1.57 \mathrm{wt} \%$ oxygen), AlN (Grade C, Starck, with $1.80 \mathrm{wt} \%$ oxygen), $\mathrm{Al}_{2} \mathrm{O}_{3}$ (CR 10, Baikalox (Baikowski Chimie, Annecy, France), 99.99 wt\%), $\mathrm{Y}_{2} \mathrm{O}_{3}$ (Ventron (Karlsruhe, Germany), 99.99 wt\%) and $\mathrm{La}_{2} \mathrm{O}_{3}$ (Fluka AG (Buchs, Switzerland), $99.99 \mathrm{wt} \%$ ). The chemical composition of the starting mixtures as well as the phase compositions $\alpha^{\prime} / \beta^{\prime}$ and the densities of the final products are presented in Table 1. The oxygen impurity in the nitrides was not taken into account. The powders were mixed by ball milling in ethanol for $50 \mathrm{~h}$ with hot-pressed silicon nitride (HPSN) balls. After drying, the mixtures were pressed uniaxially at $1 \mathrm{MPa}$, and then isostatically under $250 \mathrm{MPa}$. Specimens were $25 \mathrm{~mm}$ in diameter and $7 \mathrm{~mm}$ in thickness.

The specimens, embedded in a mixture of $75 \mathrm{wt} \%$ silicon nitride, $20 \mathrm{wt} \%$ aluminium nitride and $5 \mathrm{wt} \%$ yttria, were sintered in a gas pressure furnace first at $1800^{\circ} \mathrm{C}$ for $60 \mathrm{~min}$ under a nitrogen pressure of $0.5 \mathrm{MPa}$, followed by $1900^{\circ} \mathrm{C}$ for $30 \mathrm{~min}$ under $10 \mathrm{MPa} \mathrm{N}_{2}$. Fully dense sialon ceramics (relative density not less than 99.8 th. \%) were obtained; the overall weight loss was about $1 \mathrm{wt} \%$.

The microstructural analysis was performed by means of XRD, SEM and TEM (with energydispersive spectrometry (EDS)) observation. For SEM observations, polished specimens were etched by using Plasma Enhanced CVD under the following conditions: temperature $300^{\circ} \mathrm{C}$, pressure 600 mtorr, $300 \mathrm{kHz}, 100 \mathrm{~W}$ for 10 min with mixed $\mathrm{CF}_{4} / \mathrm{O}_{2}(5 \mathrm{vol} \%)$ with a flow rate of $200 \mathrm{ml} / \mathrm{min}$. In addition, fracture surfaces were studied by SEM. The TEM specimens were cut to thin foils of about $20 \mu \mathrm{m}$, then ion milled and coated with carbon. Besides imaging, the selected area diffraction technique was used to determine the different phases. The amount of secondary phase was calculated from TEM micrographs.

\section{SEM Observations}

Figure 1 gives the SEM fractograph of $\alpha^{\prime}$-sialon sample A. It is seen that $\alpha^{\prime}$-sialon has a homogeneous microstructure with equi-axed grains with mean grain size of approximately $4 \mu \mathrm{m}$. A very similar microstructure was found in the case of sample C which contained $2.53 \mathrm{wt} \%$ alumina in the starting mixtures. However, the addition of $\mathrm{La}_{2} \mathrm{O}_{3}$ to the starting mixture (sample E) leads to a much finergrained microstructure with a mean grain size of only $2 \mu \mathrm{m}$ (see Fig. 2), nearly a factor 2 smaller than that of sample $\mathrm{A}$.

Figure 3 presents the back scattered electron micrograph of the polished surface of sample B. The dark bars are $\beta^{\prime}$-phase, the white spots identify the amorphous phase at grain boundaries, while the matrix consists of $\alpha^{\prime}$-sialon. Figure 4 shows the

Table 1. The chemical composition of the starting mixtures and the phase composition and density of the final products

\begin{tabular}{|c|c|c|c|c|c|c|c|}
\hline \multirow[t]{2}{*}{ Specimen } & \multicolumn{5}{|c|}{ Mixture $\left(w t^{0} \%\right)$} & \multicolumn{2}{|c|}{ Final products } \\
\hline & $\mathrm{Si}_{3} \mathrm{~N}_{4}$ & $A I N$ & $\mathrm{Y}_{2} \mathrm{O}_{3}$ & $\mathrm{Al}_{2} \mathrm{O}_{3}$ & $\mathrm{La}_{2} \mathrm{O}_{3}$ & $\alpha^{\prime} /\left(\alpha^{\prime}+\beta^{\prime}\right)$ & $\begin{array}{l}\text { Density } \\
\left(\mathrm{g} / \mathrm{cm}^{3}\right)\end{array}$ \\
\hline A & $75 \cdot 41$ & 15.25 & $9 \cdot 34$ & 0 & 0 & 1 & 3.29 \\
\hline B & $87 \cdot 37$ & 7.83 & $4 \cdot 80$ & 0 & 0 & 0.75 & $3 \cdot 23$ \\
\hline C & $72 \cdot 10$ & 16.04 & $9 \cdot 33$ & 2.53 & 0 & 1 & $3 \cdot 28$ \\
\hline D & $80 \cdot 92$ & $9 \cdot 76$ & 4.79 & $4 \cdot 83$ & 0 & 0.35 & $3 \cdot 23$ \\
\hline$E$ & $71 \cdot 82$ & $14 \cdot 52$ & $8 \cdot 90$ & 0 & $4 \cdot 76$ & 1 & $3 \cdot 35$ \\
\hline
\end{tabular}




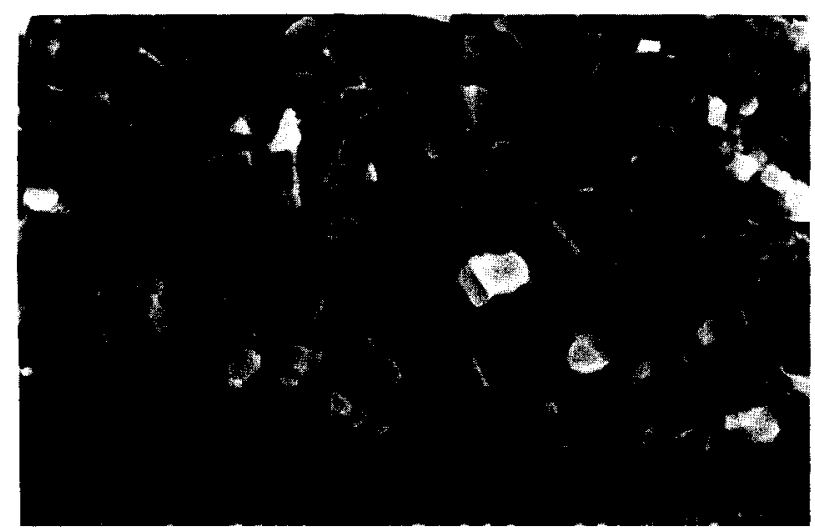

Fig. 1. SEM fractograph of $\alpha^{\prime}$-sialon sample A. The bar is $10 \mu \mathrm{m}$.

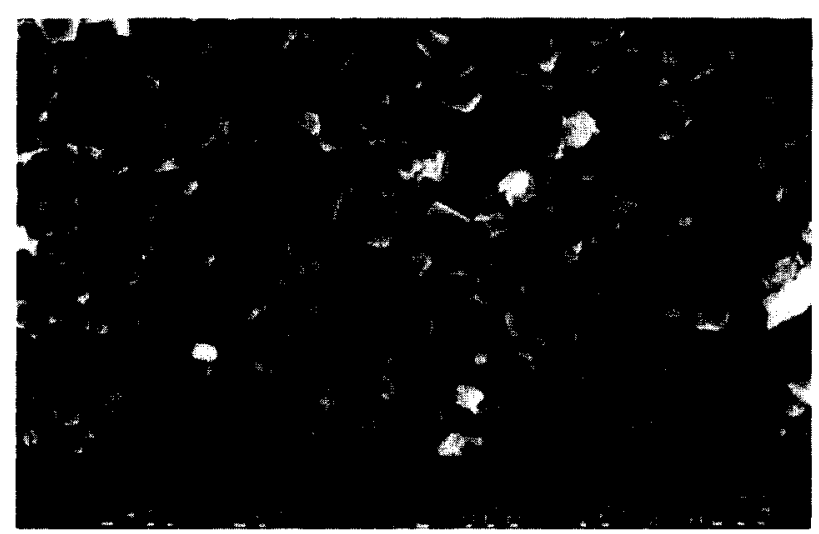

Fig. 2. SEM fractograph of $\alpha^{\prime}$-sialon sample $\mathrm{E}$ containing $\mathrm{La}_{2} \mathrm{O}_{3}$. The bar is $10 \mu \mathrm{m}$.

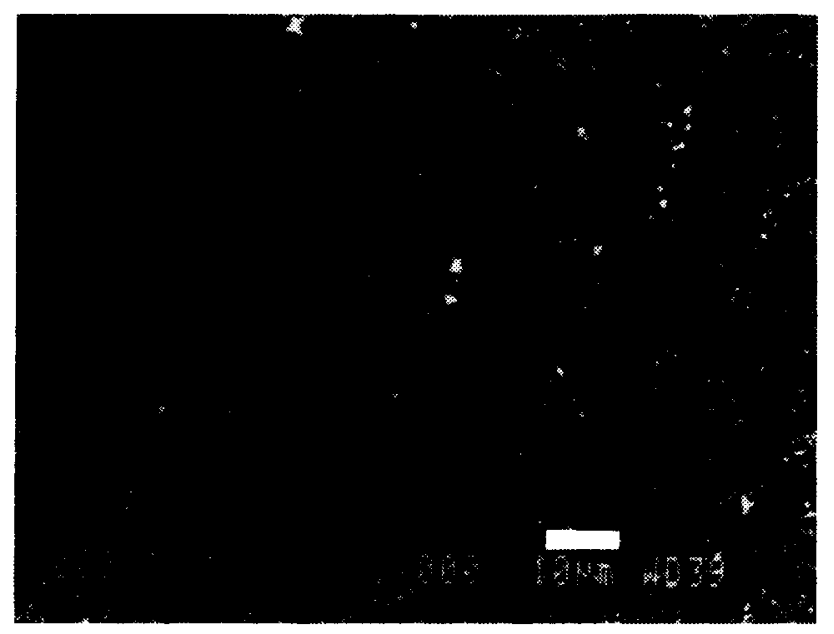

Fig. 3. The back scattered electron micrograph of the polished and etched surface of the $\alpha^{\prime}+\beta^{\prime}$ composite sample $\mathrm{B}$. The bar is $10 \mu \mathrm{m}$.

typical fracture surface of the mixed $\alpha^{\prime}+\beta^{\prime}$-sialon ceramics with $\alpha^{\prime} /\left(\alpha^{\prime}+\beta^{\prime}\right) \approx 0.75$ (sample B). It is seen that there are two types of grains: the equi-axed grains with a mean grain size of $3 \mu \mathrm{m}$ are $\alpha^{\prime}$-phase, like in monolithic $\alpha^{\prime}$-sialon ceramics, and the needleor fibre-like grains are $\beta^{\prime}$-phase with an aspect ratio of about 7 . For the $\beta^{\prime}$-phase grains an average length of about $14 \mu \mathrm{m}$ and a width of about $2 \mu \mathrm{m}$ were observed. In contrast to the monolithic $\alpha^{\prime}$-sialon

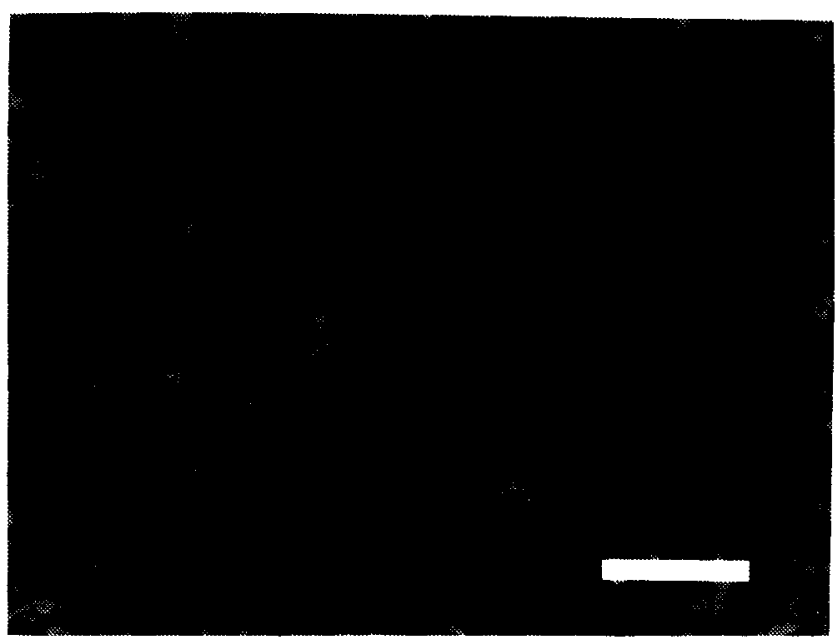

Fig. 4. SEM fractograph of mixed $\alpha^{\prime}+\beta^{\prime}$-sialon sample B. The bar is $10 \mu \mathrm{m}$.

ceramics, the addition of alumina powder to the starting mixture of the $\alpha^{\prime}-\beta^{\prime}$ composites results in a decrease of the aspect ratio of the $\beta^{\prime}$-sialon grains. In sample $\mathrm{D}$, with $\alpha^{\prime} /\left(\alpha^{\prime}+\mathrm{B}^{\prime}\right) \approx 0 \cdot 35$, an aspect ratio of about 4 was obtained with grains of $10 \mu \mathrm{m}$ in length and about $2.5 \mu \mathrm{m}$ in width, while the morphology and the grain size of the $\alpha^{\prime}$-phase remains almost the same.

\section{TEM Observations}

TEM imaging together with EDS analysis and selected-area electron diffraction technique, was applied for the study of the amount and the composition of the grain boundary phase of these sialon ceramics.

Figure 5 shows the TEM microphotograph of $\alpha^{\prime}$ sialon ceramics (sample A). Only one crystalline phase, the $\alpha^{\prime}$-sialon, was detected. Sample A contains approximately $8.5 \mathrm{vol} \%$ of an amorphous phase, which is present not only at the intersections of three and four grains, but also between two grains. This implies that all crystal grains are covered with a thin film of amorphous material. The EDS analysis indicates that the amorphous phase at grain boundaries is rich in yttrium and aluminium with an atom ratio $\mathrm{Si}: \mathrm{Al}: \mathrm{Y}=1: 0 \cdot 6: 0 \cdot 8$. This is different from the average content in the overall composition

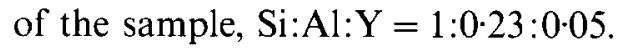

Figure 6 shows the TEM microphotograph of the mixed $\alpha^{\prime}+\beta^{\prime}$-sialon sample B. Similar to specimen A with only monolithic $\alpha^{\prime}$-sialon, a glassy phase is always observed at grain boundaries, although the amount of grain boundary amorphous phase, about $3.5 \mathrm{vol} \%$ in sample B, is much smaller. Furthermore, the composition of the glassy phase, in atom ratio $\mathrm{Si}: \mathrm{Al}: \mathrm{Y}=1: 0 \cdot 5: 0 \cdot 8$, in comparison with the overall composition $\mathrm{Si}: \mathrm{Al}: \mathrm{Y}=1: 0 \cdot 10: 0 \cdot 02$, appears quite similar to that in the $\alpha^{\prime}$-sialon material A. However, 


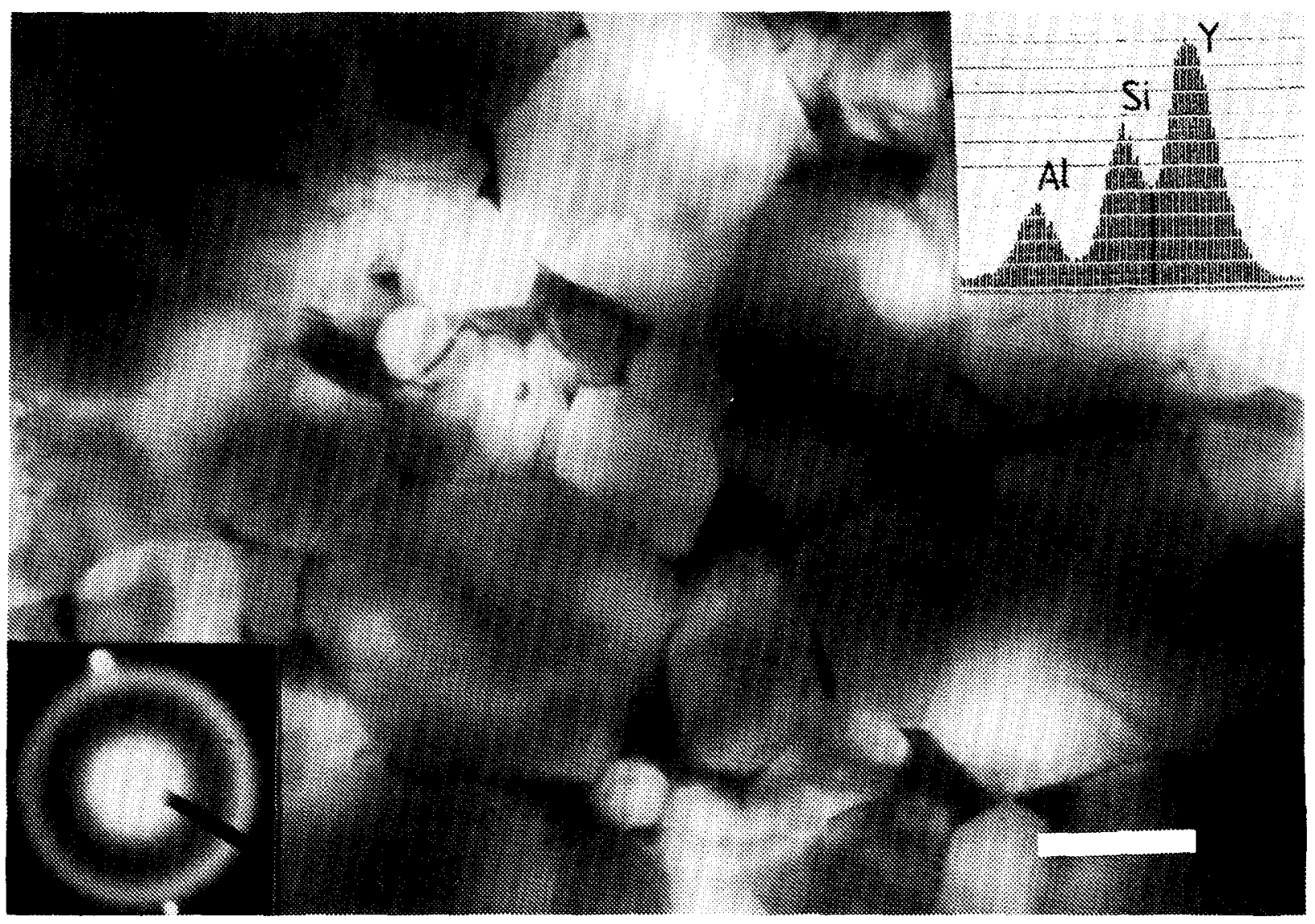

Fig. 5. TEM micrograph of sample A. The bar is $2.5 \mu \mathrm{m}$.

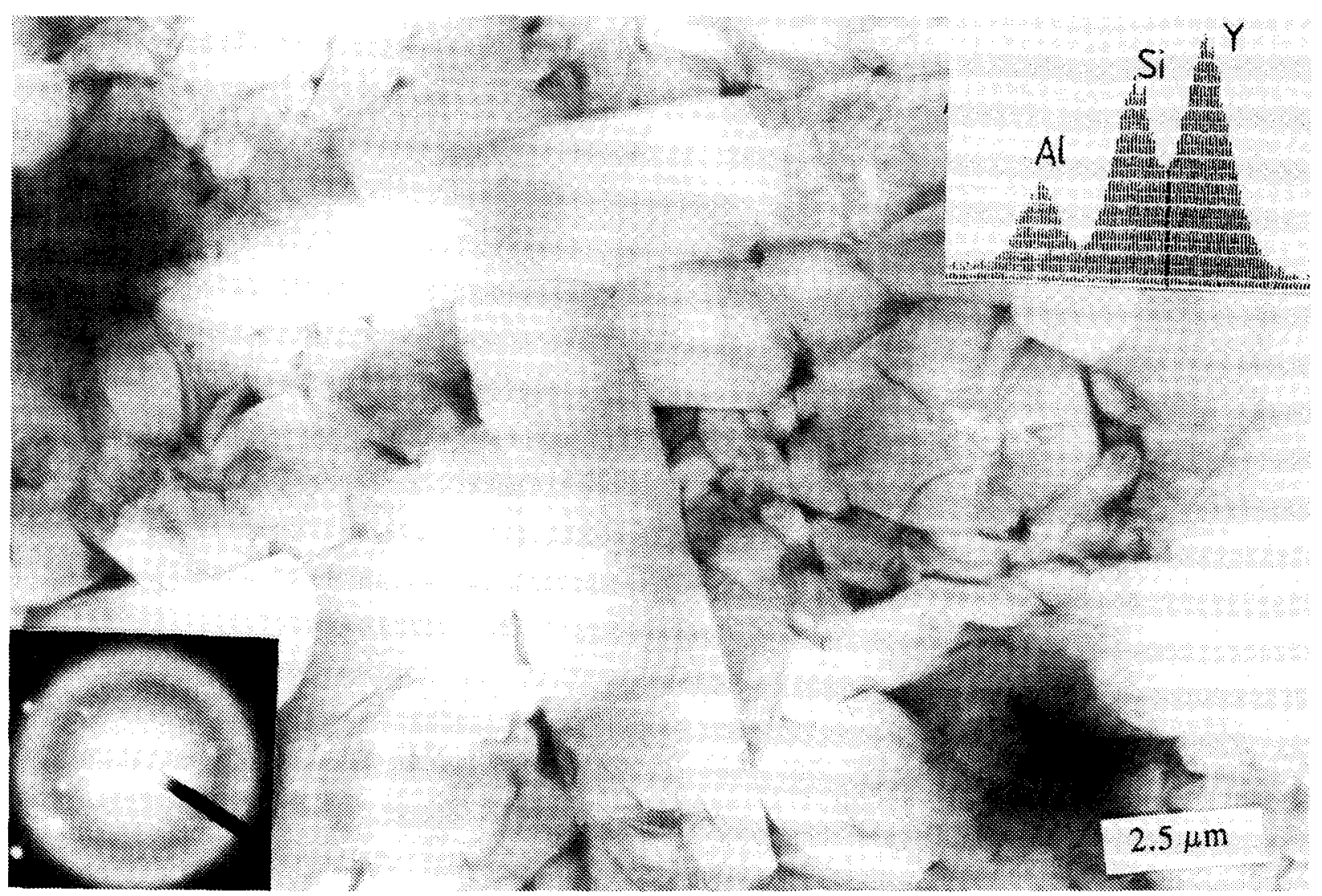

Fig. 6. TEM micrograph of sample B. The bar is $2.5 \mu \mathrm{m}$. 
here only a very thin glassy film is present between two grains.

It is seen that the amount of glassy phase at grain boundaries is slightly increased with the increased amount of alumina in the mixtures, both in the case of $\alpha^{\prime}$ - and mixed $\alpha^{\prime}+\beta^{\prime}$-sialon ceramics.

The TEM micrograph and the grain boundary composition of sample $\mathrm{E}$ are shown in Fig. 7. As pointed out above, the addition of the extra sintering additive $\mathrm{La}_{2} \mathrm{O}_{3}$ results in a fine grained microstructure. It is also seen, here, that the addition of $\mathrm{La}_{2} \mathrm{O}_{3}$ promotes the incorporation of yttrium into the lattice of the $\alpha^{\prime}$-phase while the composition of the grain boundary phase was changed to $\mathrm{Si}: \mathrm{Al}: \mathrm{Y}: \mathrm{La}=1: 0 \cdot 4: 0 \cdot 6: 1 \cdot 2$, whereas the overall composition is $\mathrm{Si}: \mathrm{Al}: \mathrm{Y}: \mathrm{La}=1: 0 \cdot 23: 0 \cdot 05: 0 \cdot 003$. However, the amount of glassy phase at grain boundaries is greatly increased to about $16 \mathrm{vol} \%$, almost doubled compared with Sample A.

High resolution TEM imaging reveals that there are many crystal defects in the $\alpha^{\prime}$-grains in sample $\mathrm{E}$, as shown in Fig. 8, which are hardly found in samples without $\mathrm{La}_{2} \mathrm{O}_{3}$ in the starting mixtures. However, it was not possible to detect the presence of $\mathrm{La}^{3+}$ ions in the crystal lattice of $\alpha^{\prime}$-sialons, showing that the solubility, if any, is very low.

\section{Discussion}

Up to now, the basic quantitative understanding of the microstructural development in $\mathrm{Si}_{3} \mathrm{~N}_{4}$ and sialon is unsatisfactory. Therefore, the emphasis in this work was placed on observing the microstructural changes depending on the composition of the starting materials and interpreting the results only qualitatively. The experimental results indicate that the addition of oxides as either structural modifiers or extra sintering additives to the starting mixtures exhibits evident influences on the microstructures of both monolithic and composite $\alpha^{\prime}+\beta^{\prime}$ sialon ceramics.

For $\alpha^{\prime}$-sialon ceramics, the authors have shown elsewhere ${ }^{8}$ that the alumina powder used in the starting mixtures reacts with yttria to form $3 \mathrm{Y}_{2} \mathrm{O}_{3} \cdot 5 \mathrm{Al}_{2} \mathrm{O}_{3}$ at moderate temperatures and then dissolves into the liquid at temperatures above $1600 \mathrm{C}$. This reduces the amount of the liquid phase at low temperatures, but results in the formation of a large amount of oxygen-rich liquid phase above $1600^{\circ} \mathrm{C}$. Therefore, grain growth is suppressed in the beginning, but proceeds faster at higher temperatures when the viscosity of the liquid is low. As a result, however, the grain sizes of the final products are almost the same. Figure 9 shows this behaviour. A similar reaction sequence was observed in the case of mixed $\alpha^{\prime}+\beta^{\prime}$-sialons. The growth of $\alpha^{\prime}$-grains is almost identical with that in monolithic $\alpha^{\prime}$-sialon ceramics; however, the variation of the quantity and viscosity of the liquid phase was seen to influence the grain growth of $\beta^{\prime}$-sialons. ${ }^{14}$ It was observed earlier for liquid phase sintering of silicon nitride ${ }^{15}$ that a high viscosity of the liquid phase leads to a slow reduction of the supersaturation and a higher aspect ratio. The authors' observation that the aspect ratio of $\beta^{\prime}$-sialon grains decreases strongly with increasing amount of alumina is in conformity with this. This influence of the degree of supersaturation indicates that there are different growth mechanisms for the basal and prism planes.

According to the phase diagrams, ${ }^{7,16,17}$ the yttria and alumina used in the starting mixtures are totally soluble in the structures of $\alpha^{\prime}$ - and $\beta^{\prime}$-sialons. However, the experimental results show that only a part of the oxides was incorporated into the crystal lattice of the final products, while the other part was consumed to form an amorphous phase remaining at grain boundaries. In general, it is seen that the increasing amount of oxides (yttria and/or alumina) results in an increasing amount of grain boundary phase. The influence of the addition of $\mathrm{La}_{2} \mathrm{O}_{3}$ on the microstructure of $\alpha^{\prime}$-sialon ceramics is significant. First, the grain size of the $\alpha^{\prime}$-phase is largely reduced, which can be explained due to the large amount of liquid phase formed during sintering. The authors have shown by dilatometry that shrinkage in the lanthanum oxide-doped samples starts as early as at $1200^{\circ} \mathrm{C}$ and reaches a first maximum at about $1400^{\circ} \mathrm{C}$. In the samples without lanthanum oxide, shrinkage starts only above $1300^{\circ} \mathrm{C}$ and reaches a first maximum rate at about $1500^{\circ} \mathrm{C}$. This clearly shows the importance of the liquid formation. The large amount of a low viscosity liquid phase results in a low supersaturation and fine, equi-axed grains. Secondly, the addition of $\mathrm{La}_{2} \mathrm{O}_{3}$ promotes incorporation of yttrium cations into the crystal lattice of $\alpha^{\prime}$ sialons. This can be expected since the distribution coefficient for the larger $\mathrm{La}^{3+}$ ions will be smaller than for the $\mathrm{Y}^{3+}$ ions. However, as a result of the formation of a large amount of an oxygen-rich liquid phase, a large amount is formed of an amorphous phase remaining at grain boundaries. Thirdly, the $\mathrm{La}_{2} \mathrm{O}_{3}$ addition leads to the formation of crystal defects in the $\alpha^{\prime}$-sialon lattice. Although it was generally accepted that $\mathrm{Ce}^{3+}$ and $\mathrm{La}^{3+}$ cations cannot be incorporated into the lattice of $\alpha^{\prime}$-sialons due to their large size, recent reports have shown that $\mathrm{Ce}^{3+}$ together with $\mathrm{Y}^{3+}$ can enter the crystal lattice, resulting in the formation of a lot of crystal defects. ${ }^{12.13}$ The authors' observation of a large number of crystal defects in the La-doped samples, which are not present in samples without La, indicates in the same direction. However, the amount of La in the crystals is too low to be detected 


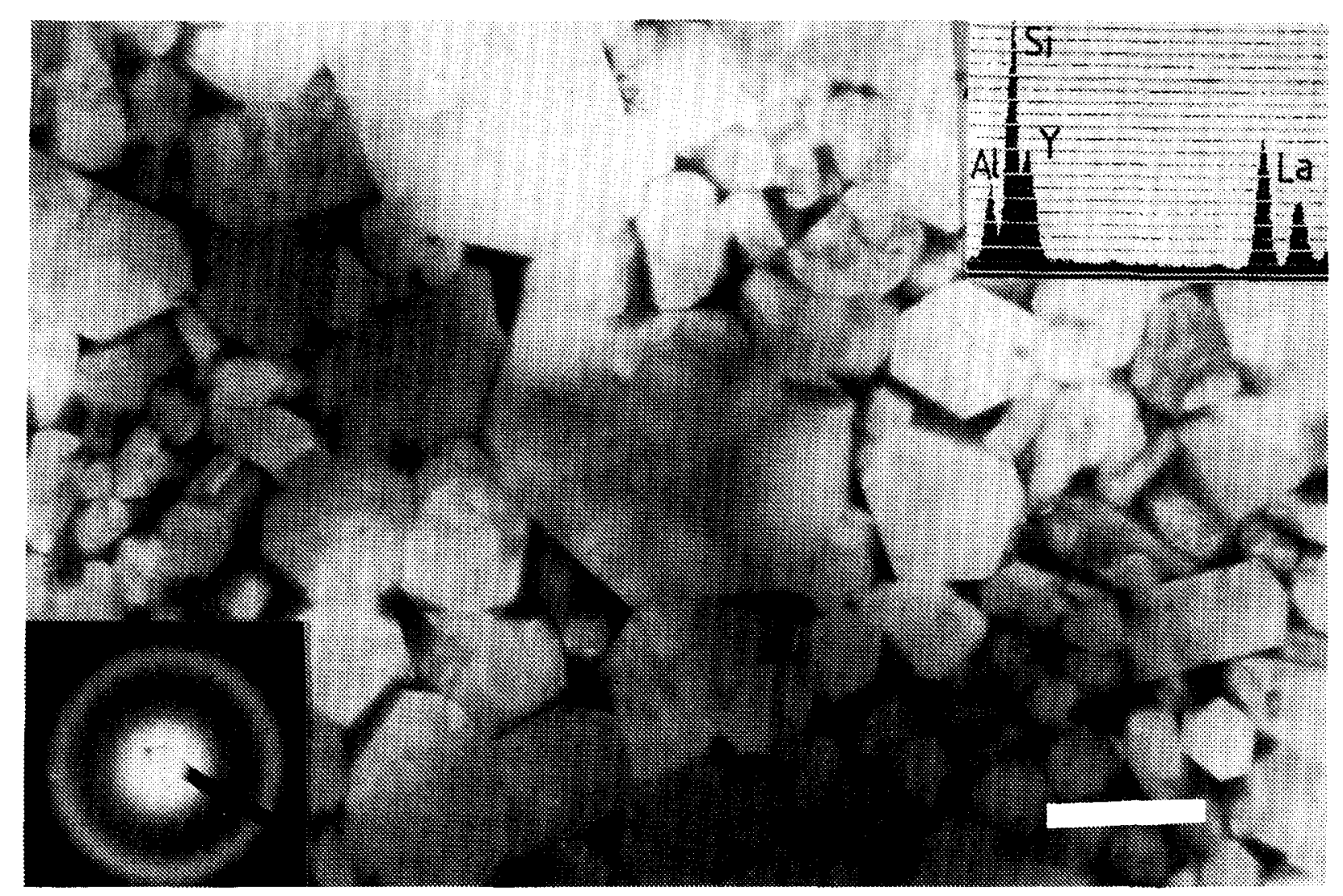

Fig. 7. TEM micrograph of sample E. The bar is $2.5 \mu \mathrm{m}$.

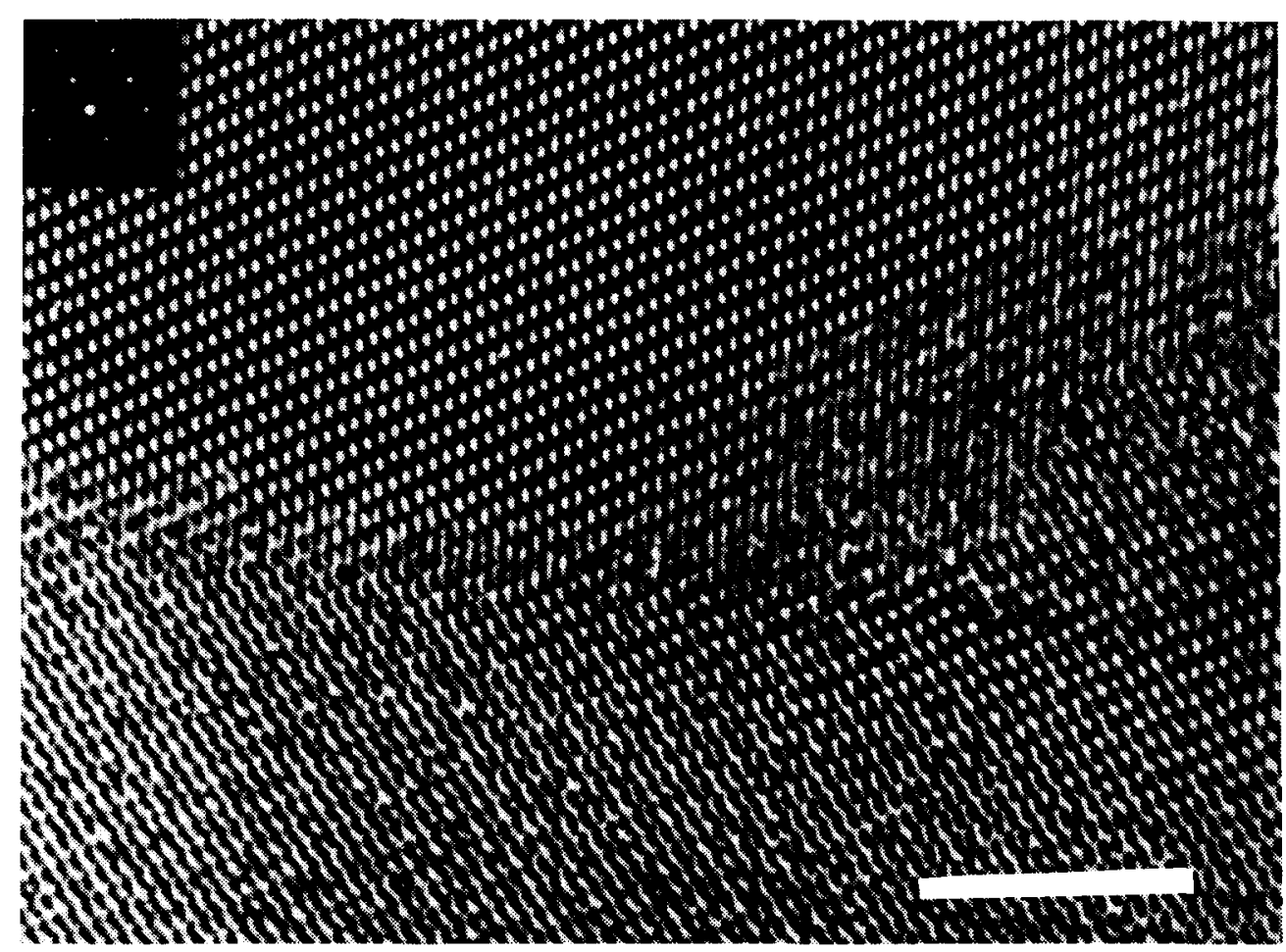

Fig. 8. High resolution TEM image of a type of crystal defects in sample E. The bar is $5 \mathrm{~nm}$. 


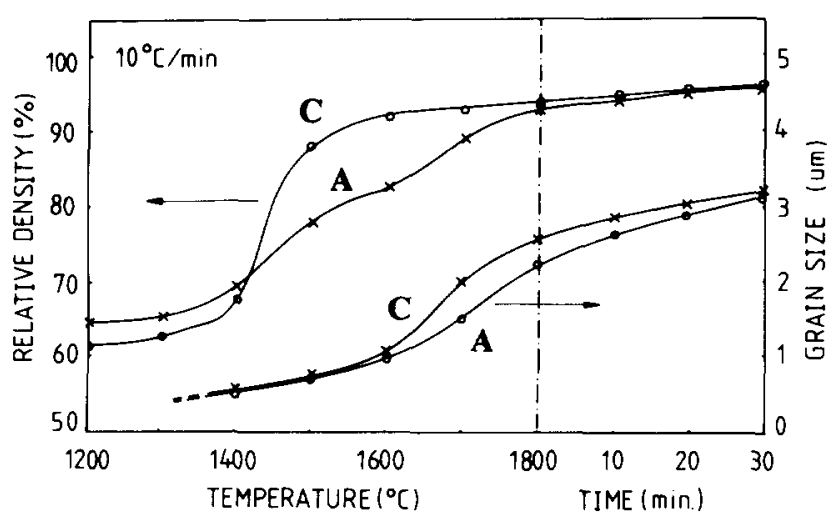

Fig. 9. Relative density and mean grain size for samples $\mathrm{A}$ and C. Heating rate $10 \mathrm{C} / \mathrm{min}$. followed by $30 \mathrm{~min}$ at $1800^{\circ} \mathrm{C}$.

by EDS. To prove this hypothesis more detailed work is necessary. Also, the mechanism of the defect formation and the type of defects remains unclear.

The oxygen impurity present in both silicon nitride (about $1.57 \mathrm{wt} \%$ ) and aluminium nitride (about $1.80 \mathrm{wt} \%$ ) has not been taken into account in the discussion above, but can nevertheless exhibit an influence on the microstructure of the final products. Qualitative considerations may lead to the changes which follow. In general, the oxygen impurity in nitrides is considered to be in the form of oxides, i.e. silica or silicon oxynitride in silicon nitride and alumina in aluminium nitride. At high temperatures these oxides will react with nitrides to form $\beta^{\prime}$ sialons in the following reactions: ${ }^{18}$

$$
\begin{aligned}
& \mathrm{Si}_{3} \mathrm{~N}_{4}+\mathrm{SiO}_{2}: 2 \mathrm{AlN} \rightarrow \beta^{\prime} \text {-sialon } \\
& \mathrm{Si}_{3} \mathrm{~N}_{4}+\mathrm{Al}_{2} \mathrm{O}_{3}: \mathrm{AlN} \rightarrow \beta^{\prime} \text {-sialon }
\end{aligned}
$$

As a consequence, for example, composite $\alpha^{\prime}+\beta^{\prime}$ sialons were obtained in the surface layer of the sintered sample C, although monolithic $\alpha^{\prime}$ sialon was expected according to the phase diagrams. ${ }^{7.16,17}$

In a similar way, the oxides also can enter the lattice of $\alpha^{\prime}$-sialons by reacting with yttria and nitrides:

$$
\mathrm{Si}_{3} \mathrm{~N}_{4}+\mathrm{AIN}+\mathrm{Y}_{2} \mathrm{O}_{3}+\mathrm{SiO}_{2}+\mathrm{Al}_{2} \mathrm{O}_{3} \rightarrow \alpha^{\prime} \text {-sialons }
$$

Therefore, an overall composition shift of sialons composition towards the oxygen-rich side is expected. Additionally, the oxygen impurities present in the nitrides were also found to increase the amount of the amorphous grain boundary phase.

\section{Summary}

It is seen that the typical microstructure of $\alpha^{\prime}$ - and mixed $\alpha^{\prime}+\beta^{\prime}$-sialon ceramics consists of crystalline phases of sialons and a small amount of amorphous phase remaining at grain boundaries; no other secondary crystal phase was found.
Increasing amounts of oxides both of structural modifiers and extra sintering additives in the starting mixtures are found to increase the amount of the amorphous grain boundary phase. The oxygen impurities not only change the overall composition of the sialons, but also result in an increasing amount of glassy grain boundary phase.

$\alpha^{\prime}$ - and $\alpha^{\prime}+\beta^{\prime}$-sialon materials show differences in microstructure. While $\alpha^{\prime}$-sialons are characterized by equi-axial grains, the $\alpha^{\prime}+\beta^{\prime}$ materials consist of equi-axial $\alpha^{\prime}$-phase and needle- or fibre-like grains of the $\beta^{\prime}$-phase.

It has been found that the addition of alumina to the starting mixtures decreases the aspect of $\beta^{\prime}$ grains, but has very little influence on the grain size of the $\alpha^{\prime}$-phase. In contrast, the addition of $\mathrm{La}_{2} \mathrm{O}_{3}$ leads to fine grained $\alpha^{\prime}$-sialon ceramics.

Although $\mathrm{La}^{3+}$ ions are too large to be incorporated into the structure of $\alpha^{\prime}$-sialons, there are indications that some $\mathrm{La}^{3+}$ ions together with small ions like $\mathrm{Y}^{3+}$ can enter the lattice of $x^{\prime}$-sialons, resulting in the formation of crystal defects.

\section{Acknowledgements}

The authors gratefully acknowledge Ing. J. P. G. M. van Eijk for his technical support and $\mathrm{Mr}$ J. W. Feng, Shanghai Institute of Ceramics, for his cooperation on the TEM observation.

\section{References}

1. Jack, K. H., In Progress in Nitrogen Ceramics, ed. F. L. Riley. NATO SAI Series E65. Martinus Nijhoff, The Hague, 1983, p. 45 .

2. Jack, K. H., In Non-oxide Technical and Engineering Ceramics, ed. S. Hampshire. Elsevier Applied Sciences, Amsterdam, 1986, p. 1.

3. Cao, G. Z. \& Metselaar, R., Chem. Mater., 3 (1991) 242.

4. Jasper, C. A. \& Lewis, M. H., 4th Int. Symp. Ceramic Materials and Components for Engines, June 1991, Gothenburg, ed. R. Carlsson. Elsevier Appl. Sci., London, 1992, pp. $188-95$.

5. Cao, G. Z., Metselaar, R. \& Ziegler, G., In Euro-Ceramics I, ed. G. de With, R. A. Terpstra \& R. Metselaar. Elsevier Applied Science, Amsterdam, 1989, p. 1.346.

6. Bartek, A., Ekström, T., Herbertsson, H. \& Johansson, T., J. Amer. Ceram. Soc., 75 (1992) 432.

7. Stutz, D., Greil, P. \& Petzow, G., J. Mater. Sci., 5(1986) 335.

8. Cao, G. Z., Metselaar, R. \& Ziegler, G., In Ceramics Today-Tomorron's Ceramics, Mat. Sci. Monographes 66B, ed. P. Vincenzini. Elsevier, Amsterdam, 1991, p. 1285.

9. Ueno, K. \& Toibana, T., Yogyo-Kyokai-Shi, 91 (1983) 409.

10. Xu, Y. R., Huang, L. P., Fu, X. R.\& Yan, D. S., Sci. Sin., A28 (1985) 556

11. Söderlund, E. \& Ekström, T., J. Mater. Sci., 25 (1990) 4815.

12. Olsson, P.-O., J. Mater. Sci., 24 (1989) 3878.

13. Ekström, T.. Jansson, K.. Olsson, P.-O. \& Persson. J. Eur. Ceram. Soc., 8 (1991) 3.

14. Cao, G. Z., Preparation and characterization of $\alpha^{\prime}$-sialon ceramics. PhD, thesis, Eindhoven University of Technology, Eindhoven, 1991. 
15. Wötting, G., Kanka, B. \& Ziegler, G., In Non-oxide Technical and Engineering Ceramics, ed. S. Hampshire. Elsevier Applied Sciences, Amsterdam, 1986, p. 83.

16. Huang, Z. K., Greil, P. \& Petzow, G., I. Amer. Ceram. Soc., 66 (1983) C96.
17. Slasor, S. \& Thompson, D. P., J. Mater. Sci. Lett., 6 (1987) 315.

18. Ukyo,Y.\& Wada, S., In Euro-Ceramics I, ed. G. de With, R. A. Terpstra \& R. Metselaar. Elsevier Applied Science, Amsterdam, 1989, p. 1.566. 